\title{
An analysis of the Poor Whites in Faulkner's Snopes Trilogy
}

\author{
Huang Xiuguo \\ School of Interpretation \& Translation, Shandong University. Weihai, Shandong Province, 264209
}

\begin{abstract}
The American literary canon witnessed the abundance of poor whites. In various works over different epochs and genres, for example, Mark Twain's The Adventures of Huckleberry Finn and George Washington Harris's SutLovingood, depression-era destitute farmers and nowadays the trailer trash, these poor whites with their frontier tall tale tradition and local color dialect, had occupied important positions. The denigration of poor whites could be traced back to 1728 when William Byrd depicted the lazy woods folk that lived in the deep mountains in Virginia in History of the Dividing Lineand Other Tracts: History of the Dividing Line (1866). Ever since, the poor whites have remained humorous and comic in southern literature. In Erskine Caldwell's Tobacco Road (1932)and George M. Weston's The Poor Whites of the South(1856), one might also find the well-established stereotype of poor whites as being a "shiftless, illiterate and often vicious group of people" (Brooks, 1963: 11). These mountain poor were related to "a range of values that provoked disapproval" (Kidd, 2004: 115). Naturally, there were exceptions, among which John Steinbeck's The Grapes of Wrath (1939) of the great depression drew wide sympathy and recognition.
\end{abstract}

KEYWORDS: Poor whites; Faulknerian

\section{INTRODUCTION}

Poor whites had also lingered in Faulkner's Yoknapatawpha world, though it was only after Absalom, Absalom!that they became central figures.

\section{About Faulknerian life experiences.}

From the earliest inklings Faulkner had about Yoknapatawpha in the early 1920s, he knew a central transformation to be reckoned with was the rise of the some so-called 'rednecks' from the dead end of tenant farming into the ranks of newly-forming middle class. (Matthews, 2009: 124)

Then and there it was the transformation of "the forgotten"- the poor whites that had been denied land and economically profitable labor in the antebellum South turned out to be the instigators of a new economic order. However, they were also the "least understood stratum in Faulkner's social structure” (Brooks, 1963: vii)and often overlooked. Compared with the myth and decline of the Southern domineering white aristocracy and the misery and racial discrimination suffered by the blacks, the poor whites had hitherto been marginal figures. He produced powerful depictions of poor white characters and families in works likeAs I Lay Dying,Light in August, Absalom, Absalom! and also the Poor Whites Trilogy.

Southern nostalgic literature tended to romanticize and idealize the Jeffersonian yeoman farmer as pastoral heroes and heroines. In I'll Take My Stand (1977), for example, the Southern agrarianism compared the Southern agrarian society to a lost paradise that human felt nostalgia for. The Twelve Southerners distinguishedthe traditionalSouthern agrarianism from the modern Northern industrialism. According to John Crowe Ransom, distinct from 
the industrial order that wasdedicated to material prosperity, the Southernersembraced his work because it permitted "the activity of intelligence" and in the antebellum era "labor itself was leisurely" (Twelve Southerners, 1977: 12, 14). These unrealistic portrayals of Southern poor whites resulted in "the whitewashing of the historical record" (Hubbs, 2008: 470). Faulkner's 1930s poor white fiction countered this unrealistic representation of leisurely labor.In contrast with this, Faulkner's portrayal of poor whites was more realistic. Eudora Welty, also a Mississippian, grasped the keen point but also overstated a little when she commented that Faulkner's The Hamlet,

In the most thorough and faithful picture of a Mississippi crossroads hamlet that you could ever hope to see. True in spirit, it is also true to everyday fact... in all its specification of detail, both mundane and poetic, in its complete adherence to social fact. (Welty, 2003: 126)

Long before The Hamlet, when Faulkner started out to work on the Yoknapatawpha series, poor peasants have presented themselves. In Light in August, Faulkner's philosophical contemplation of the dilemma of Joe Christmas as an incarnation of modern split-personality was set mainly in the rural area. From this novel emerged the wide-acclaimed Lena Grove who became the embodiment and also the mirror of rural virtues. In his avant-garde masterpiece As I lay Dying Faulkner again made use of the down trodden poor whites to symbolize the plight of modern world. Cantwell had written that Faulkner regarded himself as "a social historian, who hopes that by recording the minute changes in Oxford's life he can suggest the changes that are transforming the Whole South" (Blotner, 1991: 406). In his later works, like Poor Whites Trilogy, Faulkner abnegated the experimental writing skills and returned to the realistic ploy to work his way through the peasants.

Faulkner said he was writing about "the furious motion of being alive", which meant the protest of the human spirit against the limits put on its freedom to fulfill itself and all those forces alien to its purposes. And poor whites had always been the core of furiousness and rage. It was a kind of impotent rageagainst both the upper white planters and the "racially inferior" blacks. Poor whites' rage would explode in two directions: "racial hatred and class resentment" (Doyle, 2003: 313). Faulkner's treatment of these people had often been misunderstood simply as condescension and ridicule, but it was far more subtle and sympathetic than that. He explored their inner psychology of class and racial resentment and the social and historical context that gave rise to their 'impotent rage'.

To evaluate Faulkner's delineation of poor whites, one has to take the established tropology of poor whites image in mainstream literature into consideration. It was safe to say that Faulkner tended to engraft many canonical poor whites characteristics in the creation of his Snopes clan, for example, the grotesque obesity that was believed to a label of some of the poor whites. The specification of Flem's twin sisters'burlesque obesity was particularly stressed by the delineation that"two big absolutely static young women ... postulated that immobile dreamy solidarity of statuary" $(\mathrm{H}$ 20). And also these two girls werecharacterized as "big, identical, like two young tremendous cows", "monstrous" and "oppressive" (H 48). Their lethargy showed itself when Ratliff recalled their behavior when they got to Frenchman's Bend.

And also for Eula, besidesthe pastoral fantasy that she embodied, there was alsoher 
grotesque flesh composition, perverse fecundity and inertia despite Faulkner's efforts to defy her. From her childhood, she tried to make as little movement as possible and had to be carried to another place. Even at eleven, she occupied a body that violated its own limits, because "there was too much - two much a leg, too much of breast, too much of buttock; too much of mammalian female meat" (H 100). Her very act of being was an assertion of the grotesque. There was also the vivid representation of idiocy, exemplified by Ike Snopes, who stumbled onto the stage in Poor Whites Trilogy, salivating, empty-eyed, and trailing a homemade toy by a filthy string after him.

Besides the physical appearance, the emphasis of lack of kindred and emotional attachment in the Snopes family is also significant, another derogative association with the poor whites. Despite the fact that they were kin, there was no kinship between them. They were actually the "men (who) established the foundations of their existences on the currency of coin" (H 202). The most notable example was the domestic apathy and alienation as it has been analyzed and presented in the previous chapters. In Flem's eyes both his wife and his daughter functioned as nothing more than tools to win more economic gains. If not for this purpose they were beneath his notice. This state of affairs was not limited to his family, but ran unchecked throughout the clan. For example, Eck Snopes, who knew nothing about iron, initially was made a blacksmith to evacuate the old blacksmith from Frenchman's Bend. Subsequently he was assigned a job in Flem's newly opened grillroom in Jefferson. Because he wouldn't connive with other Snopeses to cheat customers, he was deserted by the clan and became a night watcher of the town's oil storage tank. Also, there was the illustration of how Flem first paid no heed to Mink's cry for help and then racked his brains to frame Montgomery Snopes to double Mink's sentence. And other negative qualities are embodied in portrayal of the meteoritic rise in politician Clarence Snopes who was "unprincipled and without morals" and the extreme avarice in Lump Snopes who charged fees for the peep show of the bestiality between Ike Snopes and Huston's cow. This list went long.

However, while it is certainly of great significance to be aware of Faulkner's assimilation of popular stereotypes, it is even more important to comprehend Faulkner'scontribution to the rectification and supplementation to the domineering discourse on poor whites. While some of the characters in his Poor Whites Trilogy are created in light of the same "humor and horror" as their literary precedentswere, Faulkner bestows them with "more sensitivity and greater believability" (Cook, 1976: 39).

Faulkner's delineationis everything but monolithic, which reflects essential gradations between the more popularly villainous Snopeses and other exceptionally positive characters. For example, though under the same family name Snopes, Eck Snopes and his family couldn't be more different from his namesake. The previous investigation into Eck's upstanding personality had proved that he was everything but atrocious. He "was a good man, everybody liked him" (T 99), who kept a sack of raw peanuts and handed them out to the passing children. After his calamitous death, "more people than you would have thought sent flowers" on his funeral (T 99). He also held deep affection for his family, particularly illustrated by his solicitude for his son Wallstreet (later changed into Wall by his teacher) in the episode of spotted horses' auction. He couldn't help speaking in a shaking 
voice due to his worry over his son's safety. Faulkner also portrayed how they shared a plain lunch.This loving and caring atmosphere was the core of any human community but it was alien to other Snopeses.

What Faulkner was against was not trade and market itself, but the humanity crisis incurred by it. He was very affirmative about Wall's practice in his enterprise and his commercial booming. The trilogy as a commentary on American commercialculture showed how Flem "through shrewdness and a sheer capacityfor reproduction, transcends the family legacy of sharecropping to construct arural business empire" (Skinfill, 2005: 134). Literary works on this subject were of magnitude, among which Theodore Dreiser's Sister Carrieinaugurated the discourse at the turn ofthe century and preceded Faulkner in their scrutiny of themarket's effects on American life. However, what distinguishes Faulkner's work is the historical frame of engagement, the commercial history and class identity, community values and humanity maintenance.

The introduction of Flem's modern trading mode and his inclination for universal commodification in The Hamlet dramatically affected the Community that had already seen its first sign of disintegration. The Town saw "the victory of unmasked greed and lust" (Gordon, 1997: 29) and the last efforts of Community to boycott the alien influence embodied in the abstract commodity in the form of money. In Flem, the successful headman of the Snopes clan, Faulkner revealed the predicament of members of modern society in which the interdependence and empathy vanished and each individual was only for oneself. Everyone was an interest-maximizer and all the things were offered for the sake of getting at least an equal trade-off if not more in return.

To rectify the established but also stereotypical discourse on poor whites, besides the characterization of positive figures who served as a foil to Snopeses like Flem and Lump, Faulkner also enabled the previously muted to speak out their inner thoughts. For example there was the employment of massive monologues in the Poor Whites Trilogy. What's more, with a better knowledge of the plight of the poor whites, Faulkner revealed more empathy and understanding towards them. For example Mink was reshaped from a vengeful and callous murderer into an awe-inspiring tragic fighter. Even towards the most heinous criminal Flem, Faulkner conferred certain praise on him, when he commented that the Sartoris and the De Spains had been born into money and respectability, but Flem had to "earn both of them snatch and tear and scrabble both of them outen the hard enduring resisting rock ... with one bare hand" (M 148). More than a mere rectification of the popular image of poor whites, at the end of The Mansion Faulkner even progressed to claim that the evils were not exclusively Snopes but "one of the foundation rocks of our national character itself" (M 287). Based on this we can conclude that like his transcendence over the geographical restriction, Faulkner the great "transindividual" has exceeded both his family origin and the superficialness of popular cry.

Like other great works composed by Faulkner, who engagedhimself in the individual world but still could transcend the limitation and prejudice of his personal background, the trilogy reflected the common consciousness. Despite the diversion and change, Faulkner's emphasis on humanism remained the cornerstone throughout his literary production. After getting 
tangled with the ghost of past for decades and devoting the major part of his lifetime of painstaking work to the romance of notable families like the Sartoris, the Compsons and the Sutpens, Faulkner "in the last years of his life spoke frequently of writing a Doomsday Book of Yoknapatawpha County, a kind of genealogy of the different families" (Millgate, 1989: 250). In a sense the Poor Whites Trilogy drew together the threads of the Yoknapatawpha material and served as an epilogue to his Yoknapatawpha stories. And the story of the poor whites not only occupied a predominating position in the chronicle of Yoknapatawpha but also entered into the discourse on poor whites in American Culture. It was clear that Faulkner's characterization of the Snopeses didn't merely function as a passive background but also actively participated in the current social life, which was a interaction between literature and reality in its real sense.

Though works like Absalom, Absalom! also revealed the underlying toil upon which white plantation privilege was grounded, still it constituted of Faulkner's attempts to recapture the past. In the Poor Whites Trilogy, Faulkner moved his fictional theatre to the present. Flem Snopes' aggressive struggle to climb out of poverty to social and economic prominencewas reminiscent of Sutpen's "design" to accomplisharistocracy through material wealth. But distinct fromSutpen of Absalom, Absalom!Flem did not fall victim to his own fantasies. "Flem's compound ability to sell without buying allows him to cope with the new industrial age and the commodity culture images that this age generates."(Kaiser, 2006: 6) In this sense Sutpen was depicted as a synecdoche figure for the idealized old south when pure will could achievemagnificence. Flem indicated a present of commodity culture and a future of fetishization.

To a certain extentthe Snopes Trilogyis not an allegory of foreign and alien force that erodes the Camelot but an admonition for the possible plight of extreme commodification rationality in the future. What distinguished Faulkner's literary production was not his nostalgia for an idealized past or the vain efforts to eulogize an irrevocable decadence, but the abundant humanity that prevailed throughout his works. This was most notable in his compassion for both the bereavement of the downfallen ruling class and the torture suffered by insulted and the downtrodden. The Snopeses' collapse also indicated that it was the humanism values within us that made us human and its absence implicated our doom. In his fierce denunciation of the inhumanity inclination represented by Flem resided Faulkner's deep apprehension over the excessive instrumental rationality and commodification with the arrival of modern society based on free-contract. In Flem's final death at the hand of his consanguinity, however, also contained Faulkner's wishful hope or romantic conviction that the inalienable and undying humanity that dodged somewhere would eventually counter back and deliver humans from the final destruction.

When the battle comes it always produces a Roland. It doesn't mean that they will get rid of Snopes or the impulse which produces Snopes, but always there's something in man that don't like Snopes and objects to Snopes and if necessary will step in to keep Snopes from doing some irreparable harm. (Gwynn\&Blotner, 1977: 34)

\section{CONCLUSIONS}

The majority of existing criticism tended to considerthat Faulkner was preoccupied with formal experimentation to the pint of 
obliviousness and indifference to the tenor of the times. However, the critical analysis here demonstrated that Faulkner's works especially his late fiction was "far more politically challenging and politically radical'(Urgo, 1989: 4) than it had been acknowledged to be.The Snopes Trilogy gave us "remarkable insight into Depression history and culture on the basis of his expansive social vision" (Atkinson, 2005: 8). Among all the subjects, the poor whites characters as the core of indignation expect more recognition and exploration.

\section{References:}

[1]. Atkinson, Ted.Faulkner and the Great Depression: Aesthetics, Ideology, and Cultural Politics. Athens: University of Georgia Press, 2005.

[2]. Brooks, Cleanth. William Faulkner: the Yoknapatawpha Country. New Haven: Yale University Press, 1963

[3]. Cook, Sylvia Jenkins. From Tobacco Road to Route 66: the Southern Poor White in Fiction. Chapel Hill: University of North Carolina Press, 1976.

[4]. Doyle, Don Harrison. "Faulkner's County: the Historical Roots of Yoknapatawpha." Journal of Southern History 69(2003): 291-326.

[5]. Faulkner, William. The Hamlet. New York: Random House, 1940.

[6]. __. The Town. New York: Vintage, 1961.

[7]. __. The Mansion. New York: Vintage, 1965.

[8]. Gordon, Hayim. Fighting Evil: Unsung Heroes in the Novels of Graham Greene. Westport: Greenwood Press, 1997.
[9]. Gwynn, Frederick L and Joseph L Blotner, eds. Faulkner in the University: Class Conference at the University of Virginia, 1957-1958. Charlottesville: Charlottesville University of Virginia Press, 1977.

[10]. Hubbs, Jolene. "William Faulkner's Rural Modernism." Mississippi Quarterly 61.3(2008):461-475.

[11]. Kaiser, Wilson. Exchanging Values: a Comparison of Flaubert's Concept of Irony in Madame Bovary and Faulkner's Reading of Commodity Culture in Absalom, Absalom!.Diss.University of North Carolina at Chapel Hill, 2006.

[12]. Kidd, Stuart. "Visualizing the Poor White". A Companion to the Literature and Culture of the American South. Eds. Gary, Richard, and Owen Robinson. Malden: Blackwell Publishing, 2004. 110-130

[13]. Matthews, John T. "Many Mansions: Faulkner's Cold War Conflicts." Global Faulkner: Faulkner and Yoknapatawpha, 2006. Eds. Annette Trefzer and J Ann Abadie. Jackson: University Press of Mississippi, 2009. 3-24

[14]. Millgate, Michael. The Achievement of William Faulkner. Athens: The University of Georgia Press, 1989.

[15]. Skinfill, Mauri. "The American Interior: Identity And Commercial Culture in Faulkner's Late Novels." The Faulkner Journal 21. 1/2(2005):133-144.

[16]. Urgo, Joseph. Faulkner's Apocrypha: a Fable, Snopes, and the Spirit of Human Rebellion. Jackson: University of Mississippi Press, 1989

[17]. Welty, Eudora. On William Faulkner. Jackson: University Press of Mississippi, 2003. 